environmental laws, the conventional strategy by which presidents make policy changes, were largely rebuffed by Congress, which in turn had been subjected to increasing pressure from the public, both directly and through revitalized environmental groups. But Congress has little control over administrative decisions; while it could partially restore ravaged budgets, it could not force administrators to spend the money.

To a large extent, as the authors make clear, the administration's actions have been counterproductive to their intended ends. The fiasco at the EPA not only defeated the goal, once shared by regulated industries and environmentalists alike, of reforming the existing regulatory framework to make it more effective, efficient and fair; it backfired. By politicizing regulatory affairs, and either firing or alienating the EPA's professional staff, the EPA administration under Gorsuch set back the clock on much needed regulatory reassessment. Richard Andrews, author of the chapter on the EPA, comments:

The attempt to achieve radical policy change by means of ideological loyalist appointees untainted by experience thus stands as probably the single most reckless tactic, and clearest failure, in Reagan's policy strategy.

Similarly, the administration's efforts to weaken the Clean Air Act may have led to more, not less, rigidity in regulation and increased mistrust between regulators and the regulated.

The Reagan team's actions have also been self-contradictory. Complaining on one hand that insufficient information existed to justify certain programmes, it proceeded to kill research projects that could provide the necessary data. Describing the relinquishment of the Department of
Energy's responsibilities for datacollecting and analysis, Regina Axelrod drily observes: "No government in recent times has sought to beat its opponents by declaring war on information".

Professors Vig and Kraft have produced not only a stinging critique of Ronald Reagan's environmental policies, but a useful, general text on the making and implementing of environmental policy at the federal level in the United States. Its viewpoint is generally pro-environment, yet it is sympathetic to the needs of business and industry for reasonable, consistent and even-handed environmental regulations. The book unfortunately suffers from a certain amount of repetition and overlap, but that perhaps is an inevitable result of the difficulty in orchestrating the efforts of 17 authors.

Beyond its value as a text on environmental policies, the book provides an instructive case-history of an "administrative presidency" - a presidency that effects policy changes through administrative decisions. In this instance, the changes have been both unprecedentedly radical and lacking public consensus. Political scientists no doubt will find food for thought for years to come, not only in the lessons the Reagan presidency offers for eluding the complex checks and balances built into the government's structure and the degree of change that it successfully brought about despite them, but also in the failure of the American public to hold Ronald Reagan personally responsible for policies that it clearly does not support.

Anne H. Ehrlich is a Senior Research Associate in the Department of Biological Sciences, Stanford University.

\section{Boffin's progress}

\section{Robert Cockburn}

\section{Bernard Lovell: A Biography.}

By Dudley Saward.

Robert Hale, London: 1984. Pp.320.

f12.95.

BORN in Gloucestershire in 1913, Sir Bernard Lovell is a worthy successor to the bold buccaneers who thrived in the West Country during the reign of the first Elizabeth. He is a man of ruthless energy, an outstanding scientist, an engineer faute de mieux, but above all an inspired leader.

The author of this biography was a Group Captain on the staff of Bomber Command during the Second World War, collaborating closely with Lovell, and he has remained an intimate friend of the family ever since. So Saward is well qualified to write a definitive account of Lovell's life and works, though he sometimes tends to include facts from his own experience which are not particularly rele- unprepared for night bombing and its performance over Germany was lamentable. The introduction of $\mathrm{H}_{2} \mathrm{~S}$, first into the Pathfinders and then to the main bomber force, improved its efficiency by an order of magnitude. It was to this end that Lovell directed his redoubtable energies; he transgressed every rule in the book, scrounged endlessly, and by sheer bloody-mindedness cut through all the usual organizational restraints. It was a personal achievement of the highest order. As the end of the War came in sight, and the pressures on TRE eased, many of the leading figures collapsed after four years of unremitting toil. Lovell was no exception, although he recovered rapidly.

As soon as he arrived back at the University of Manchester in 1945, Lovell applied himself with characteristic determination to equipping the green-field site at Jodrell Bank with apparatus purloined from the Services, and to laying the foundations for his subsequent career as a radioastronomer. It was in 1950 that the idea for a huge steerable telescope caught his imagination, and the fruitful collaboration with H.C. Husband commenced Husband was the only engineer in the country prepared to design such a novel and advanced structure. Nowadays we are inured to the inevitable escalation of costs during the development of an advanced project. At that time the Department of Scientific and Industrial Research, the funding agency, was unused to such expensive investments, and throughout the seven years that it took to bring the telescope into operation there was continuous wrangling over finances. Used to the lavish wartime expenditure, Lovell found peacetime restraints irritating in the extreme; but loyally backed by Manchester University, and by P.M.S. Blackett and other far-sighted senior scientists, he forced the project through with the same drive that he had used with such effect during the War. There were undoubtedly frequent bouts of depression and frustration, but his resolve remained firm.

At the very last stage, when the equipment was on the verge of operation, public opinion swung in his favour when it was realized that the telescope was the only facility in the world capable of tracking the Sputniks. For the next three years Jodrell Bank was used by both the Americans and the Russians as a vital tracking station for their space probes. Lovell was by now an international figure, and was invited to the United States and USSR where he was received with the greatest courtesy and respect, and was able to arrange several collaborative projects.

In addition to all his research work Lovell found time to write a large number of books and give lectures, and for numerous public duties. As a member of the Science Research Council and chairman of the Astronomy Space and Radio Board, he became involved in wider issues of national policy. At one point, in 
the late 1960s, he generously supported Ryle's synthesized aerial at Cambridge even though this meant abandoning his own cherished ambition for a thousandfoot telescope. But despite his involvement in so many national issues and recurring budget cuts, Lovell continued over the years to update and extend the facilities at Jodrell Bank, culminating in the multitelescope interferometer which has vastly improved the resolution available. Manchester University now has a research centre which will keep it in the forefront of radioastronomy for many years, an

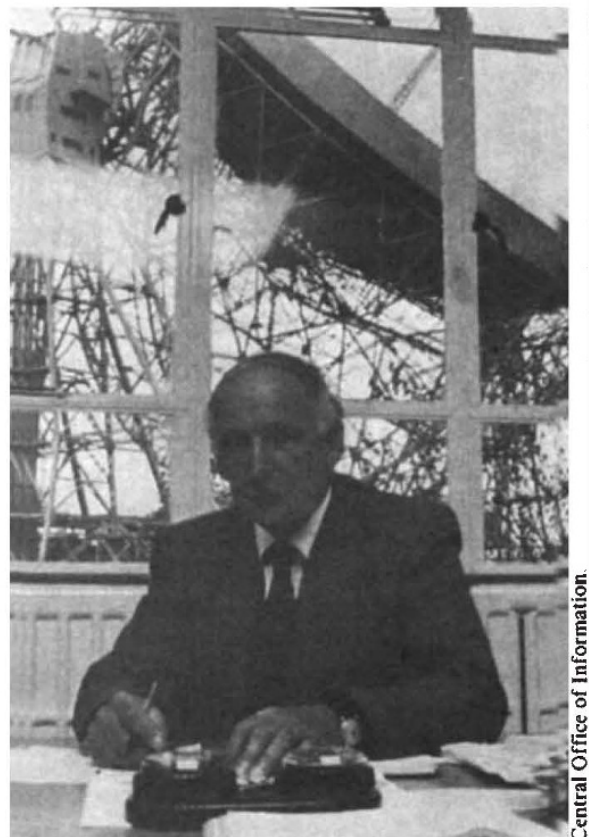

Man and machine - Bernard Lovell at Jodrell Bank, 1977, with the telescope in the background.

impressive monument to one man's ability, ingenuity and dogged determination.

Apart from giving his readers a portrait of Lovell, in this book Saward provides a valuable insight into the efforts necessary nowadays to bring about a major scientific advance. It is no longer sufficient to convince one's peers of the scientific merits of a particular project. These have to be explained in terms which a layman can appreciate. Allies have to be courted, doubters converted and critics confounded. Expenditure must be justified against competing projects and the campaign will need to be sustained for many years.

The biography concludes with Lovell's retirement in 1980 as Professor of Radioastronomy at Manchester. But this cannot be the end of the story - it somehow seems unlikely that he will be content to pass his lime cultivating the garden, playing the piano and watching cricket, his leisure interests listed in Who's Who.

From 1939 to 1945 Sir Robert Cockburn worked on radar at the Telecommunications Research Establishment, Malvern. He was later Chief Scientist of the Ministry of Aviation and Director of the Royal Aircraft Establishment, Farnborough.

\section{The bomb and the bumble-bees}

\section{Walter Gratzer}

\section{Late Night Thoughts. *}

By Lewis Thomas.

Oxford University Press: 1984. Pp.175. £9.95.

"Is ditchwater dull? Naturalists with microscopes have told me it teems with quiet fun." Thus G.K. Chesterton, and his words could serve as a text for some of Lewis Thomas's best essays. This, his third collection, will not disappoint his devotees, who will find here the familiar blend of reminiscence and reflection, the excursions into etymology, and withal an artful simplicity of style, illuminated by periodic shafts of startling insight. Thomas descants on health care, the funding of science and the nuclear arms race; he ruminates on the march of molecular biology, on natural history and the benefits of biomedical research. One of the threads that runs through his discourse is his entrancement with the intricacies of nature; Thomas sees the Earth as a kind of exquisitely crafted, bejewelled Fabergé egg,

the loveliest object afloat round the sun, enclosed in its own blue bubble of atmosphere, manufacturing and breathing its own oxygen, fixing its own nitrogen from the air into the soil, generating its own weather at the surface of its rain forests, constructing its own carapace from living parts.

There is touch of mysticism here, as also elsewhere, for example in his fascination with the mind of the bee.

The second thread that runs through the book is a bracing optimism about science, present and future - the only game in town, Thomas calls it - with perhaps even a hint of hubris; the problems engendered by science, he believes, will be put right by scientists, iatrogenic diseases cured by doctors. He even has a good word for the embattled discipline of sociology, which he expects soon to see emerge as an exact science.

These robust views contrast oddly with his dark perception of a future with the Bomb. Brooding on the unthinkable, he gives vent to the following: "If I were very young, sixteen or seventeen years old, I think I would begin, perhaps very slowly and imperceptibly, to go crazy". Thomas is not, to my mind, at his best in this rhetorical vein; what one looks for from a writer and scientist of his stature is something more reasoned that an evocation of the horrors of Hiroshima: Freeman Dyson, in his admirable series of articles in the New Yorker (now a book), showed that it can be

*In the United States Late Night Thoughts on Listening to Mahler's Ninth Symphony, published by Viking, $\$ 12.95$. done with no loss of impact. But as that eupeptic divine, Sydney Smith remarked about his own meditations on the human condition, cheerfulness will keep breaking in; Thomas proposes, as a safeguard against nuclear war, huge armies of conscript hostages, American and Russian, to be kept in perpetual motion across each others' countries, lodged in luxurious Pullman trains, full of beer, running to undisclosed timetables. Such travel would both broaden the minds of the soldiery and restore the railways to solvency, while ensuring that no missile ever leaves its launching pad.

The book abounds in such jeux d'esprit. Thomas's imagination is caught, for example, by the biology of the lie-detector: if the telling of a lie causes sufficient anxiety that it should reveal itself in a measurable physiological change, he wonders, are there perhaps other manifestations, such as secretion of a peptide or some other product from the skin, that could be detected and quantitated by microanalytical techniques? And is there then a genetic basis for the ethical imperative, a biochemical morality? Dr Thomas explores with some relish the social consequences that such a discovery might bring in its train. (Ambrose Bierce, on the other hand, defines conscience as a small, still voice that warns you that someone may be watching.)

Many of these essays will serve splendidly for starting dinner-table conversations; the "Seven Wonders of the Modern World", for instance, should be a diverting game to play (even though $\mathrm{Dr}$ Thomas's first nomination - the bacterium that was supposed to thrive at $250^{\circ} \mathrm{C}$ under pressure in thermal vents under the Pacific Ocean - has already been exposed for an illusion, due probably to contamination by a less aristocratic organism).

Thomas's purpose is also more serious, however, for he does not address himself only or even primarily to scientists. I do not believe there is anyone writing today who better represents to the outside world how basic and applied research, and indeed scientists, function. He makes clear for example the essential unpredictability of the process of discovery. It was the organic chemist, Homer Adkins, who defined basic research as shooting an arrow into the air, and where it lands painting the target. The implications of this truth have urgently to be brought home to our paymasters, the public, and their none-too-obedient servants, the politicians. Let us hope Late Night Thoughts falls into the hands of some of the more literate of them and that some of the lessons penetrate their preconceptions. The rest of us will settle for the continuing stimulation and entertainment that Dr Thomas so gracefully affords.

Walter Gratzer is in the Medical Research Council's Cell Biophysics Unit, King's College, University of London. 